\title{
THE ACHAEAN FEDERAL IMPERIAL CULT II: THE CORINTHIAN CHURCH
}

\author{
Bruce W. Winter
}

\section{Summary}

The petition from Argos discussed in the previous essay is a 'new' document for New Testament scholars which throws light on first-century issues in Roman Corinth. This paper seeks to examine the Argive evidence in order to see what information it might yield to help in our understanding of the early Christian community. In particular it will explore the problem of the imperial cult and 1 Corinthians 8 and comment briefly on Roman Corinth's cultural and legal mores.

In the preceding article Anthony Spawforth has drawn attention to a document about Corinth which was previously unknown to New Testament scholars. It throws light on the formation of the federal or provincial imperial cult which was established there in the early years of the church. This is significant for a number of reasons.

Firstly, given the shortage of literary evidence we possess generally on the East in this period when compared with other eras, it is important for the way it discusses religious, cultural and administrative matters and the relationship between Rome and the eastern part of the empire.

Secondly, the Corinthian literary sources have also been enhanced by its recovery. The corpus consists of two pagan authors, Strabo and Pausanias, who as 'tourists' described in detail the city a century before and after the formation of the church, and two visitors, Favorinus and Epictetus, in the early second century. This petition from neighbouring Argos is the only major, non-Christian literary source we possess that refers to first-century developments in this illustrious Roman colony. ${ }^{1}$

1For some but not all texts on Corinth see J. Murphy-O'Connor, St. Paul's Corinth: Texts and Archaeology (Wilmington: Michael Glazier, 1983). For 
Up to this point, the only literary remains of substance which reflected the life, laws and customs of Corinth have been 1 and 2 Corinthians and Acts 18:1-18. Paul still remains the only author who knew the city in depth through residing there for some eighteen months.

Thirdly, what is most important for New Testament studies is that we now have a petition that reflects a development in Corinth which occurred at approximately the same time as 1 Corinthians was written.

The purpose of this essay is to examine the petition from Argos to see what light it throws on 1 Corinthians for (I) the imperial cult and Christianity and (II) the particular cultural milieu against which it is to be understood.

\section{The Imperial Cult and the Church}

We know that a local imperial cult was established early in the founding of the colony of Corinth. ${ }^{2}$ What is said of the East generally could also be said of Achaia: 'The diffusion of the cult of Augustus and of other members of his family in Asia Minor and throughout the Greek East from the beginning of the empire was rapid, indeed almost instantaneous' ${ }^{3}$ Contrary to the popular perception of New Testament scholars, emperor worship was subsequently neither rejected by Tiberius, nor did it lie dormant until the reign of Domitian, except for spasmodic periods in the reigns of Caligula and Nero. ${ }^{4}$ It continued to be promoted in the empire by all the Julio-Claudian emperors. ${ }^{5} \mathrm{It}$

additional sources see Philostratus, Life of Apollonius iv. 26, Epictetus, Diss. III.1, and also the Augustan poet, Crinagoras of Mytilene in A.S.F. Gow and D.L. Page, The Greek Anthology I (Cambridge, 1968) no. 37.

2D. Engels, Roman Corinth: An Alternative Model for the Classical City (Chicago: University of Chicago Press, 1990) 102.

35. Mitchell, Anatolia. Land, Men, and Gods in Asia Minor (Oxford: Clarendon Press, 1993) I. 100.

4See for example E. Ferguson, Backgrounds of Early Christianity (Grand Rapids and Carlisle: Eerdmans and Paternoster, 1987) 163.

${ }^{5}$ See most recently the general discussion by D. Fishwick, The Imperial Cult in the Latin West, vols. I, 1-2, II, 1-2 (Leiden: Brill, 1987-1992) where the cult in the East is discussed for comparative purpose with the West; S.R.F. Price, The Imperial Cult and Asia Minor (Cambridge: CUP, 1984); and most 
has been suggested that the Corinthian epigraphic sources 'show the Corinthian aristocracy's devotion to (or even obsession with) the imperial cult', a comment based on the fact that of the thirty-one extant references to priests in Roman Corinth, twenty refer to those of the imperial cult. ${ }^{6}$ The Argive petition demonstrates that imperial veneration was truly alive and expanding in Achaia in this period. It confirms other contemporary evidence of widespread support in the East. ${ }^{7}$

Do we have any evidence that a local or provincial imperial cult had any impact on the theological beliefs of the early Christian community in Corinth? It has been argued that the long-established local imperial cult did not create the problem for early Christians that one would have expected in this Roman colony. 8 There, Roman citizens venerated the deified Julius Caesar and Rome' and provincials worshipped 'Augustus and Rome' as they were required to do elsewhere in the empire. ${ }^{9}$ The reason for this was that Gallio, the noted jurist, refused to proceed with the case of the Jews $v$. Paul. He ruled that Christianity was a movement within Judaism and that the case being brought forward simply involved an internal dispute about 'words and names and your own law' as he put it (Acts 18:15). This judgement meant that all Christians, whether Roman citizens of Corinth or provincial, Jews or Greeks in Achaia, belonged to a religio licita and were thereby exempted from imperial veneration.

Given that this was the case, is it likely that the subsequent creation of the provincial cult could in any way disturb the Christian community in Corinth? There are a number of reasons for arguing that the imperial cult did unsettle some members of the church, and this seems to be

recently S.J. Friesen, Twice Neokoros: Ephesus, Asia and the Cult of the Flavian Imperial Family (Leiden: Brill, 1993).

${ }^{6}$ Engels, Roman Corinth, 102.

7For a summary in various provinces see my 'Acts and Roman Religion' edd. D.W.J. Gill and C. Gempf, The Book of Acts in its Graeco-Roman Setting, The Book of Acts in its First Century Setting (Grand Rapids and Carlisle: Eerdmans and Paternoster, 1994) 93-7.

${ }^{8}$ For discussion of the imperial cult implication for Christians following Gallio's judgement see my 'Acts and Roman Religion', 98-103.

${ }^{9}$ Dio Cassius, 51.20.6-7. 
reflected in 1 Corinthians 8. Paul's discussion comes as a response to a written request for a ruling by some Corinthian Christians 'concerning the things sacrificed to idols' and more specifically 'about the eating of things sacrificed to idols' (1 Cor. 8:1, 4). The circumstances giving rise to the Christian community's question about eating this food are explained by Paul. Some Christians were exercising what he terms 'this right of yours' ( $\dot{\eta} \dot{\varepsilon} \xi o v \sigma i \alpha$ v $\mu \hat{\omega} v \alpha \tilde{v} \tau \eta)$. It was one that enabled them 'to sit at meat in an idol temple' (1 Cor. 8:9). This right was also possessed by some 'weaker' Christians who were initially reluctant to exercise it because they were uncertain as to the appropriateness of doing so. 10

What was this 'right'? It could not be to eat meat in the idol temple of Demeter or Asclepius, since attendance at a meal there was not seen as a 'right'.11 Access to activities in the temples of Demeter and Asclepius were open to everyone.

However, there was a 'right' some possessed in Corinth which entitled them to eat at a feast in a temple. This was at the Games. An inscription records that Regulus 'was [the first] to preside over the Isthmian Games at the Isthmus... gave a banquet for all the colonists (epulumo omnibus colonis)' ${ }^{\prime}{ }^{12}$ This celebration occurred when the Games were first held in Isthmia. It has been recently argued that when the famous Games were returned to Corinth from Sikyon soon after the former was constituted a Roman colony, they were actually held in the colony's stadium, theatre and hippodrome. ${ }^{13}$ They

${ }^{10}$ There is no justification for translating $\varepsilon$ ' translated in chapter 9 as 'right'. The cognate, $\dot{\varepsilon} \lambda \varepsilon v \theta \varepsilon \rho \circ \varsigma$, of the actual Greek term for 'freedom' or 'liberty' (غ่ $\lambda \varepsilon v \theta \varepsilon \rho i \alpha)$ occurs some five verses later, 9:1, while the term $\dot{\varepsilon} \xi o v \sigma i \alpha$ is used 6 times in chapter 9. It can only be translated as 'right' in 8:9. For a discussion of this see my Seek the Welfare of the City: Early Christians as Benefactors and Citizens (Grand Rapids and Carlisle: Eerdmans and Paternoster, 1994) 166-8.

${ }^{11}$ For a discussion of this see my Seek the Welfare of the City, 170-71.

12Kent, Corinth VIII. 3, 73 and E.R. Gebhard, 'The Isthmian Games and the Sanctuary of Poseidon in the Early Empire' in ed. T.E. Gregory, The Corinthia in the Roman Period, Journal of Roman Archaeology Supp. 8 (Ann Arbor, 1994) 87-8.

13E.R. Gebhard, 'The Isthmian Games and the Sanctuary of Poseidon in the Early Empire', 82-3. As she notes "Isthmia and Caesarea held in Corinth" is found on a statue base honouring a victory, and also that the 
were only later moved to Isthmia when the renovation of buildings was completed. The date suggested for its return to its ancient site is uncertain, although A.D. 23 and 51 have been suggested.14

The 'right' to attend several dinners in the temple of Poseidon in Isthmia must, in these circumstances, have been a civic one which was restricted to Corinthian citizens i.e. Roman citizens, in contrast to provincials (incolae) who lived in Corinth. Subsequently the president of these famous imperial Games continued to entertain all the citizens of Corinth. Not to be outdone by Regulus, subsequent presidents 'wined and dined' them on several occasions during particular games, as Plutarch notes in his first-hand observation. ${ }^{15}$ Paul's discussion indicates that some Christians might, by their example, persuade others to participate in feasts in the idol temple (1 Cor. 8:10). If the feasts being referred to were connected with the Games, then it suggests that some Christians turned down an initial invitation from the president but were tempted to accept subsequent civic invitations, including dinners celebrating the imperial cult. 16

It would seem that the particular occasion which gave rise to eating sacrificial meat in the idol temple had not occurred while Paul was present, but arose after he left. In dealing with the Corinthian problem he could cite no previous teaching which he gave while in Corinth, although immediately after this lengthy discussion he commends the Corinthian Christians for observing the traditions which he delivered to them during his eighteen months' stay (1 Cor. 11:2). It cannot be argued that Paul tolerated Christian converts continuing to eat food in the idol temple because of his description of conversion given in a letter written from Corinth. He indicates that it involved 'turning to God from idols to serve the true and living God' (1 Thess. 1:9). The conclusion can be drawn that

Caesarean games are frequently referred to as being held 'in Corinth', 867.

${ }^{14}$ E.R. Gebhard, 'The Isthmian Games and the Sanctuary of Poseidon in the Early Empire', 82-9.

15Plutarch, Quaes. Conviv. 723A.

16 On feasting at the cult celebrations see Price, Rituals and Power, 109. 
new circumstances occurred which caused this problem, and Christians possessed no definitive teaching to meet this particular situation-hence their written request.

The argument of those who exercised their right is clear from Paul's letter-'we know that "an idol is nothing in the world", and that "there is no God but one"' (1 Cor. 8:4).17 This apparently provided sufficient theological justification for particip-ation at a feast in a pagan temple for some Christians.

Does Paul's response to this issue give any clues concerning the problem created by the world of religious pluralism including the imperial cult? He discusses the matter of eating food in the temple initially in relation to pagan ways of thinking about the deities and the Christian view. He observes that 'even though there are so-called gods, whether in heaven or earth; as there are many gods and many lords, but for us there is one God, the Father... and one Lord, Jesus Christ... ' (1 Cor. 8:5-6). This evidence is revealing on a number of counts. The construction 'so-called' (oi $\lambda \varepsilon \gamma o$ orvor) implies that they were popularly, but erroneously, designated gods by pagans. ${ }^{18}$ This inappropriate designation is related to 'the gods in heaven or on the earth'-a somewhat unusual dichotomy for pantheism to use, if Paul is speaking simply of the traditional pagan deities whom he designates variously as 'gods', 'lords' or 'daemons' (1 Cor. 8:5, 10:20). There were gods on earth i.e. statues which the pagans believed were the gods. A century later Pausanias records that there was no shortage of them in the agora and surrounding area. ${ }^{19}$ Among those in Corinth were statues of living or deceased emperors together with those of their families. Furthermore, we know that they were referred to

${ }^{17}$ Translators now put these statements in quotation marks to signal that they were verbatim comments from the Corinthian's letter to Paul.

18For linguistic evidence that 'so-called' means a 'popular but erroneous designation' see my 'In Public and in Private: Early Christians and Religious Pluralism' in edd. A.D. Clarke and B.W. Winter, One God, One Lord: Christianity in a World of Religious Pluralism (ed 2; Grand Rapids and Carlisle: Baker and Paternoster, 1992) 143-5.

${ }^{19}$ For a summary of this description by Pausanias see my 'Theological and Ethical Responses to Religious Pluralism-1 Corinthians 8-10', Tyn.B. 41.2 (1990) 211-13. 
as 'deified', as were living members of their families. ${ }^{20}$ There are good reasons then for suggesting that when Paul speaks of 'gods on the earth' he included the emperor and his family. In fact, the imperial cult may well have been specifically in his mind when he made that statement and could account for the dichotomy of 'in heaven' and 'on earth'.

In addition, Paul may be using athletic and boxing imagery and the essential discipline involved for sportsmen and women in his discussion of the Corinthian's problem. Athletics and boxing were important components for one of the three groups into which events at the Games were divided.21 They would be highly apposite allusions if the problem was connected somehow with the Isthmian Games (1 Cor. 9:24-27).

There was a nexus in Corinth between the celebration of the imperial cult and the Isthmian games. 'Even the Isthmian Games were linked to the imperial cult through the Caesarean Games and Imperial Contests'.22 With the coming of the provincial imperial cult, that connection would be fortified in the year when the Caesarean Games were held.

Are there known dates for the holding of the games? There were the biennial minor Isthmian Games and also the major quadrennial Caesarean Games and Imperial Contests. It is known that Nero himself attended the Caesarean Games in A.D. 67 and this would mean that the quadrennial Games were held in 55.23 The date of 1 Corinthians is attributed to the same year as the Caesarean Games and Imperial Contests and the year after that suggested for the creation of the federal cult.

Why would Christians wish to participate in feasts in the temple? The epigraphic evidence has established that it was a civic right possessed by reason of Corinthian citizenship. That Paul devoted substantial discussion to the issue of foregoing his rights in relation to his own activities and warnings from

${ }^{20}$ For example, Antonia Augusta, the grandmother of Claudius, was deified c. A.D. 18 in the reign of Tiberius and continued to be venerated up to and after her death. N. Kikkinos, Antonia Augusta: A Portrait of a Great Lady (London and New York: Routledge, 1992) 98.

${ }^{21}$ Engels, Roman Corinth, 52.

22Engels, Roman Corinth, 102.

${ }^{23}$ See Kent, Corinth, VIII. 3, 31 for evidence of presidents in 51 and 59. 
the Old Testament of divine judgement for idolatry, ${ }^{24}$ suggests that the privilege was one that some Christians were extremely reluctant to forego for reasons of social privilege or demonstrations of civic loyalty. There was always the problem of social pressure from institutions and neighbours in this highly civic-minded and corporate society, especially in a firstcentury Roman colony. S. Mitchell's comments, although not made in connection with Corinth, are highly apposite to the situation, in that they help explain the enormous pressures.

One cannot avoid the impression that the obstacle which stood in the way of the progress of Christianity, and the force which would have drawn new adherents back to conformity with the prevailing paganism, was the public worship of the emperors... it was not a change of heart that might win a Christian convert back to paganism, but the overwhelming pressure to conform imposed by the institutions of his city and the activities of his neighbours. ${ }^{25}$

Paul's immediate task was to persuade those who had attended meals in the temple to desist, partly because by their example they put pressure on weak Christians who could be drawn back into paganism (1 Cor. 8:10-12). Although they were not obligated to observe the cult because of Gallio's judgement, some Christians saw no theological conflict. They had a strong justification-'an idol is nothing' and 'there is no God but one' (1 Cor. 8:4). Yet, even the theologically 'confident' Christians who were so certain that they were unaffected by eating in the idol temple were warned to flee the trap of idolatry and the incompatible membership of the two tables (1 Cor. 10:12, 14, 21). Over-confident and weak Christians alike were in danger, such was the power of privilege and the importance of the imperial cult, and more so when it was established on a federal basis and celebrated in Corinth.

${ }^{24}$ See B. Rosner, "No Other Gods": The Jealousy of God and Religious Pluralism' in One God, One Lord: Christianity in a World of Religious Pluralism, ch. 7.

25Mitchell, Anatolia: Land, Men, and Gods in Asia Minor, II. 10. For a summary of the festive activities and discussion in relation to Galatia see my 'Civic Obligations: Galatians 6:11-18' Seek the Welfare of the City, ch. 7. 


\section{The Cultural Milieu}

Whether Corinth was Greek or Roman in its cultural milieu has long occupied scholars. This is important not simply to help describe the city, but in some instances exegetical issues are determined in part on judgements made on this matter. ${ }^{26}$

A recent discussion suggested that it was misleading to see an historical or cultural discontinuity between Greek and Roman Corinth, because of the century that elapsed in which it 'lay desolate'. This argument was based on a particular interpretation of the evidence for continuity. In response, strong arguments were marshalled which show that the Greek city was effectively dismantled and destroyed, and its rich treasure looted in 146 B.C. When the Roman colony was founded in 44 B.C., there was a preference for Roman 'modernisation' rather than the restoration of Greek 'authenticity'. 27 The reconstruction of Corinth indicates that it was laid out according to Roman town-planning centuriation. The only concession was to the line of some of the ruined buildings around the agora. These were either rebuilt, as in the case of the long stoa or remodelled and extended as was done with the temple of Apollo.28

26See for example F. Lyall, 'Roman Law in the Writings of Paul-The Slave and the Freedman', NTS 17 (1970-71) 73-9 and my 'Acts and Roman Religion', 100 on the local support for Rome's anti-semitism (Acts 18:17). 27W. Willis, 'Corinthusne deletus est?', BZ 35 (1991) 233-41 and the reply by D.W.J. Gill, 'Corinth: A Roman Colony of Achaea', BZ 37 (1993) 259-64 who assembled and interpreted the evidence, and showed what civic discontinuity meant. Gill also cites C.K. Williams III, 'The Refounding of Corinth: Some Roman Religious Attitudes', in edd. S. Macready and F.H. Thompson, Roman Architecture in the Greek World (London, 1987) 26-37. C.K. Williams III who is the Director of the Corinth Excavation, American School of Classical Studies in Athens told the present author that to see Corinth as anything but Roman in its structures and outlook is to misread the archaeological and epigraphic evidence.

28See D.G. Romano, 'Post-146 B.C. Land Use in Corinth, and Planning of the Roman Colony of 44 B.C.', in ed. T.E. Gregory, The Corinthia in the Roman Period, Journal of Roman Archaeology Supp. 8 (Ann Arbor, 1994) 930. On Roman town plans and buildings see E.J. Owens, 'Roman Town Planning', in ed. I.M. Barton Roman Public Buildings, Exeter Studies in History 20 (Exeter, University of Exeter, 1989) ch. 1 and E.J. Owens, The 
The Argive petition provides important evidence substantiating its adherence to Roman law and customs. It yields vital indicators that the laws and customs of Ancient Greece were not those which the Corinthians followed-they did not 'respect the high authority of the ancient laws and customs', but 'rather those which it seems they took over from the sovereign city'. Had Corinth valued the heritage of Greek Corinth it would have meant that the payment of heavy tribute for extravagant entertainment for the provincial cult would not have been sought from Argos (409C). The petition suggests that this was not how the Corinthians saw this issue, for 'in reliance on the laws they now have, they claim that their city has gained the advantages since they received the colony from Rome' (409D). The reference to the expensive purchase of bears and panthers for 'hunting shows' and not for gymnastic or musical contests shows Corinth's preferences were for the former. That was a Roman innovation, while the latter epitomised true, i.e. Greek, culture ( $\left.\pi \alpha \_\delta \varepsilon i \alpha\right)$ (409A). While the implications of this for Corinthian studies cannot be explored in detail within the purview of this essay, ${ }^{29}$ it is clear that the Argive petition provides important literary confirmation of Corinth's loyalty, preference for, and adherence to Roman customs and laws.

The above study has sought to demonstrate the Argive petition's potential to enrich our understanding of important aspects of life in Roman Corinth. It immediately lays to rest perceptions that the imperial cult in the reigns of Claudius and Nero was of little or no significance at all in Corinth. It supports conclusions drawn from archaeological and non-literary evidence that Corinth was clearly a Roman, not a Greek city. Because early Christianity did not always take root in GraecoRoman cities, but in the case of Corinth, in a Roman colony, cognizance must be taken of its Roman laws and customs where a first-century background is invoked for exegetical purposes. This petition is an exciting find and one that will enrich the study of 1 and 2 Corinthian and Acts 18:1-18.

City in the Greek and Roman World (London and New York: Routledge, 1991).

${ }^{29}$ This will be explored in my book on social changes and secular mores in 1 Corinthians (forthcoming 1996). 